\title{
The Quality of Work Life in Egypt
}

\author{
Tarek A. El Badawy (Corresponding author) \\ Assistant Professor of Management \\ Business Administration Department, Auburn University at Montgomery \\ Alabama, United States of America \\ E-mail: tarek.elbadawy@aum.edu
}

Enas Shiha

Teaching Assistant, The German University in Cairo

Cairo, Egypt

Email: enas.osman@guc.edu.eg

Mariam M. Magdy

Research Associate, The German University in Cairo

Cairo, Egypt

E-mail: Mariam.ahmed-magdy@guc.edu.eg

Received: August 25, 2016 Accepted: September 14, $2016 \quad$ Published: October 7, 2016

doi:10.5296/wjbm.v2i2.9943 URL: http://dx.doi.org/10.5296/wjbm.v2i2.9943

\begin{abstract}
This study investigates the meaning of quality of work life and what are the common dimensions of quality of work life in Egypt. Employees are the most important asset in any organization. Researchers defined quality of work life as a multidimensional concept companies adopt in order to provide better working conditions for employees to make them more satisfied and comfortable in the organization. A questionnaire was distributed to a sample of 100 employees in order to highlight the most important dimensions of quality of work life. The research was exploratory in nature. Results showed that compensation, job security and personal growth and opportunity to learn new things are the most important dimensions of quality of work life In Egypt. Further findings and implications are provided.
\end{abstract}

Keywords: Work Life, Work-life, Egypt, Human resources 


\section{Introduction}

Organizations should understand the importance of human resources (Kanten, 2014; Saklani, 2010) and to what extent people can provide huge value for their employers (Chan \& Wyatt, 2007). Researchers found that employees are the reason behind organizations' success or failure. Accordingly, organizations need to adopt the quality of work life concept in order to maintain satisfied employees and have positive behaviors that improve job performance (Kanten, 2014). It is argued that quality of work life is a concept that focuses on the job itself, leisure of the employees and family life of the employees (Chitakornkijsil, 2010). Jayakumar and Kalaiselvi defined the quality of work life as the strategies and principles that emphasize the importance of the employee's well-being in work life (2012). These principles provide conditions regarding what makes the best workplace and work environment (Jayakumar \& Kalaiselvi, 2012).

The purpose of this study was to explore the meaning of quality of work life, the dimensions of quality of work life and the measurements to find out what are the most important dimensions of quality work life among Egyptian employees. The importance of the quality of work life has been increased due to the great effect of the challenges, competition and technology on the working conditions so that all organizations started to draft policies and strategies in order to satisfy employee demands and needs (Kanten, 2014).

The remainder of this paper is organized as follows. The first part gives an overview on the quality of work life origin, definitions, importance and objectives. The following part discusses the different dimensions of quality of work life. The final part in the literature discusses different methods to measure the quality of work life based on satisfying seven needs. The literature is followed by the methodology, results, discussion and concluding with limitations and recommendations for future research.

\section{Literature Review}

\subsection{Quality of Work-Life}

Tavy Stock Institution of Human Relation did a great effort researching problems that face workers and it proposed a model called the socio-technical system. The study concentrated on how to make employees satisfied and how to respond to their needs. It also analyzed the importance of the quality of work life in all organizations under investigation (Jayakumar \& Kalaiselvi, 2012; Zare et al., 2014). It was concluded that quality of work life not only encompasses the life at workplace, but also everything related to employees such as rewards, benefits, job security, working conditions and interpersonal relationships. All these aspects, consequently, have a great effect on personal life outside the organization (Jayakumar \& Kalaiselvi, 2012). However, Kanten (2014) believed that the quality of work life is merely the working conditions that enable the organization to operate effectively and efficiently. Researchers do not agree, currently, on the concept which erupted in the management field recently. Jayakumar and Kalaiselvi believe it was introduced in the 1950s (2012). Others argue that the concept was introduced in the 1960s (Kanten, 2014; Zare et al., 2014) in USA, Japan and other industrialized countries in Scandinavia. However, Dehghan Nayeri et al. (2011) and 
Hsu and Kernohan (2006) state that the concept of quality of work life was introduced in 1930 by Mayo.

\subsection{Quality of Life as a Multi-Dimensional Concept}

Quality of work life is a multidimensional concept making it very complicated to explore (Dehghan Nayeri et al., 2011; Rathi, 2009; Tatawar \& Nambudiri, 2014). It means removing the undesirable behavior and adding or modifying the working conditions in order to gain the desirable behavior and a favorable environment (Islam, 2012). It is a very subjective concept depending on the employees' perceptions of working life (Kanten, 2014; Rathi, 2009; Sundaray et al., 2013). Employees' perceptions are affected by some factors such as job load, working conditions, ability to grow, compensation and working environment (Islam, 2012). These perceptions affect the individual's decision whether to apply for, stay with or leave the organization (Sundaray et al., 2013). In addition, they affect the employee's interactions and responses to the work environment and the characteristics of the work itself (Igbaria et al., 1994). Quality of work life was also defined as a process that organizations adopt in order to satisfy employees' needs (Jayakumar \& Kalaiselvi, 2012; Kanten, 2014; Rathi, 2009; Sundaray et al., 2013; Tatawar \& Nambudiri, 2014) and make them able to have full authority in making decisions regarding their work life.

Quality of work life is very beneficial for both employees and employers (Zare et al., 2014). Organizations with high quality of work life can achieve the highest rates of growth and profitability (Huang et al., 2007). The researchers argue that when organizations want to attract and retain the most skilled employees, they need to apply the quality of work life principles (Huang et al., 2007; Sundaray et al., 2013) to improve satisfaction of employees and increase learning abilities (Sundaray et al., 2013). Quality of work life is associated with high levels of commitment (Huang et al., 2007; Igbaria et al., 1994; Kanten, 2014; Rathi, 2009; Saklani, 2010), motivation (Igbaria et al., 1994; Kanten, 2014; Saklani, 2010) and involvement of the employee (Tatawar \& Nambudiri, 2014). It is also associated with increases in productivity (Pranee, 2010; Saklani, 2010), improvement in the standard of living and putting positive attitude as a mindset (Jaykumar \& Kalaiselvi, 2012). It does not only affect positive behaviors but also reduces negative ones such as level of absenteeism (Chan \& Wyatt, 2007; Rathi, 2009; Tatawar \& Nambudiri, 2014; Zare et al., 2014), productivity issues (Chan \& Wyatt, 2007) and turnover rate (Zare et al., 2014; Huang et al., 2007; Kaushik \& Tonk, 2008; Tatawar \& Nambudiri, 2014).

\subsection{Dimensions of Quality of Work Life}

Prenee (2010) proposed one classification of quality of work life that divided the quality of work life into three different aspects: physical aspect which consists of working conditions, economic aspect which consists of wages and salaries and the psychological aspect which consists of the kind of work and how to do it. Another classification was proposed by Tatawar and Nambudiri, they classified quality of work life into consideration work, emotional state, learning and improvement, social relationship, self-realization and physical state (2014). The most common classification of quality of work life was based on eight dimensions, this classification is called Walton's classification (Kanten, 2014). 


\subsubsection{Walton's Quality of Work Life Classification}

Adequate and Fair Compensation; Compensation is the most important and basic dimension of quality of work life (Kanten, 2014; Sundaray et al., 2013). The same researchers argue that compensation is the main reason behind increasing motivation. However, others argue that the compensation is important but not sufficient for employees to feel satisfied in their jobs (Huang et al., 2007). Compensation should not only be linked to performance and achievement of tasks (Sundaray et al., 2013), but also linked to the profitability of the organization (Pranee, 2010).

Safe and Healthy Working Conditions; Safe and healthy environment is one of the most important issues that organizations deal with every day (McLain, 1995). It is no longer accepted to involve workers in hazardous working environments (Sundaray et al., 2013). There are many attributes that can affect the health and safety of the employees such as noise, fumes and heat (Chitakornkijsil, 2010) beside the chemical, radiological, physical and biological issues (McLain, 1995). The environment and the working conditions should be comfortable enough to help employees do their work in a better way and ensure safety for workers who are operating dangerous machines and equipment (Kanten, 2014).

Opportunity to Develop Human Capabilities; Kanten believed that all organizations should provide learning and training programs for their employees in order to help them improve skills, be autonomous and be independent (2014). Such training programs should be planned thoroughly to ensure high returns for the organizations (Vidal-Salazar et al., 2012). When organizations make efforts to develop their human potential, employees will be satisfied, stress levels and conflicts will be reduced and accordingly job performance will improve (Kanten, 2014).

Opportunity for Growth and Security; All employees should have equal chance to grow, improve their abilities and skills and develop their personalities (Sundaray et al., 2013). Security is a non-monetary reward (Noble, 2008), it depends on employees' perception (Zeytinoglu et al., 2012). When employees feel secure, they will be satisfied (Kanten, 2014; Noble, 2008) and will face lower levels of stress (Wang et al., 2014). Job security not only leads to increased levels of commitment among employees (Wang et al., 2014) but also reduces the intention to leave and turnover rates (Noble, 2008).

Social Integration; Kanten believed that employees should get involved in their work, feel that they are an important part of the organization and get the feeling of belonging (2014). Social integration is defined as the interaction between employees themselves and the interaction between the managers and their employees (Riches \& Green, 2003). O'Reilly also highlights the degree to which an employee has a satisfied relationship with other co-workers as part of the social integration definition (1989).

Constitutionalism; One of the rights that employees have is the right to know how they are protected in the organization. There are many types of protection organizations can provide such as personal privacy and labor law which protects the employees' rights and equality in the distribution of rewards and benefits (Kanten, 2014) and provide the freedom of self-expression (Kanten, 2014). 
Total Life Space; Total life space indicates the free time employees have in their lives to spend on leisure activities. In other words, organizations should guarantee the work/life balance of the employees (Kanten, 2014). Rama Devi and Nagini found that the majority of employees experience high levels of stress at work that affect their personal life (2013).

Social Relevance; Social relevance is the social responsibility of any organization (Nagypal, 2014). Organizations should be ethical and provide code of ethics for employees to ensure fair treatment without discrimination (Kanten, 2014). In addition, codes of conduct ensure the ethicality in some issues such as financial transparency (Christensen et al., 2014). Organizations should protect the environment and prevent all activities that harm and destroy natural life (Kanten, 2014; Nagypal, 2014) and counter bribery issues (Nagypal, 2014).

\subsection{Measurement of Quality of Work Life}

Quality of work life can be measured by assessing some factors such as turnover rate, job stress, autonomy (Dehghan Nayeri et al., 2011; Zare et al., 2014), security, economic rewards (Islam, 2012), fair compensation, work involvement, commitment, working conditions, working complexity, personal growth, union management relations and support, intention to leave and inner meaning of work to personal life (Dehghan Nayeri et al., 2011). Chan and Wyatt (2007) explain the measuring of quality of work life in terms of measuring the hierarchical levels of needs proposed by Maslow. The common method of measurement is through measuring the eight dimensions of quality of work life discussed before (Jayakumar \& Kalaiselvi, 2012; Tatawar \& Nambudiri, 2014).

After reviewing the literature, a gap was identified concerning the investigation of the most important dimensions of quality of work life in Egypt. Hence, the research question proposed was "What are the most important dimensions of quality of work life in Egypt?"

\section{Methodology}

\subsection{Sample}

The sampling technique used was the non-probability approach, convenience sample due to time and cost constraints. One-hundred participants completed the questionnaire. They were employed in different Egyptian organizations. The questionnaire was sent electronically and participants were asked to complete it. Anonymity was assured.

\subsection{Instrument}

The questionnaire developed by Cornell (1984) was used as it was previously tested and validated. The first part of the questionnaire consisted of administrative questions. The second part of the questionnaire was a Likert scale consisting of 11 statements about certain dimensions of work life. Participants were required to read each statement and choose how much they would like to have each characteristic in their own jobs. The third part of the questionnaire was a Likert scale consisting of 12 statements about two different jobs and employees were required to choose between both of them which one they strongly prefer, slightly prefer or feel neutral about. 


\section{Al Macrothink}

\subsection{Analysis}

The analysis method used was simple descriptive analysis to know the frequency of each characteristic. Analysis of variance one-way (ANOVA) was used to determine whether there is statistically significant difference between the dimensions of quality of work life or not. The last analysis was Z-test for two mutually exclusive proportions from one group used to determine if the difference between two proportions is statistically significant or not.

\section{Results}

One-hundred participants completed the questionnaire. $49 \%$ were males and $51 \%$ were females. Their ages ranged from 21-31 years old (81\%), 30-45 years old (15\%) and 45-60 years old $(4 \%)$.

\subsection{Frequencies}

The results showed that $37 \%$ like to have respect and fair treatment extremely much. $36 \%$ rated having respect and fair treatment as very much liked (Figure 1).

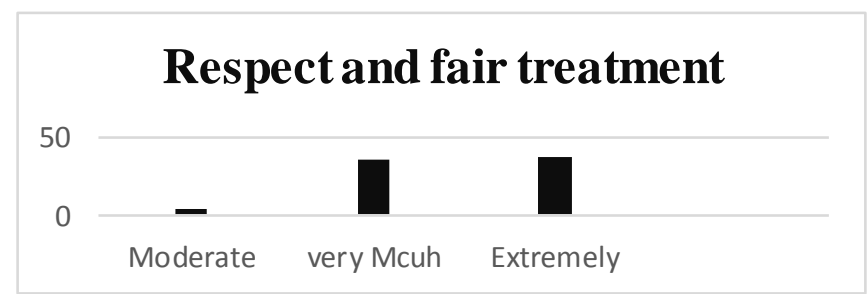

Figure 1. Dimension respect and fair treatment

As shown in Figure 2, having challenging work only had $13 \%$ like to have this extremely much. However, the majority of participants like to have this very much (34\%).

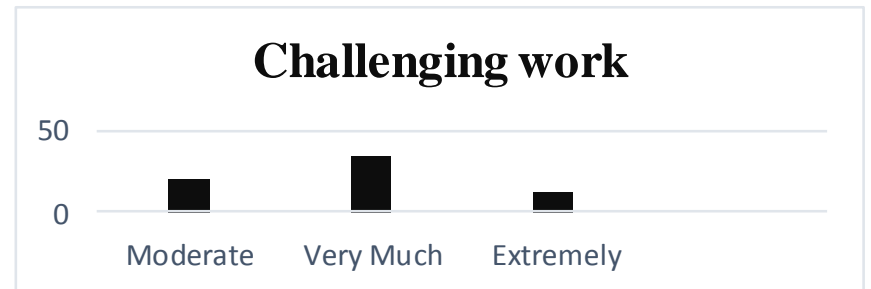

Figure 2. Challenging work

For the independent thoughts and actions, the majority is either like to have this very much $(37 \%)$ or extremely much (24\%) (Figure 3$)$. 


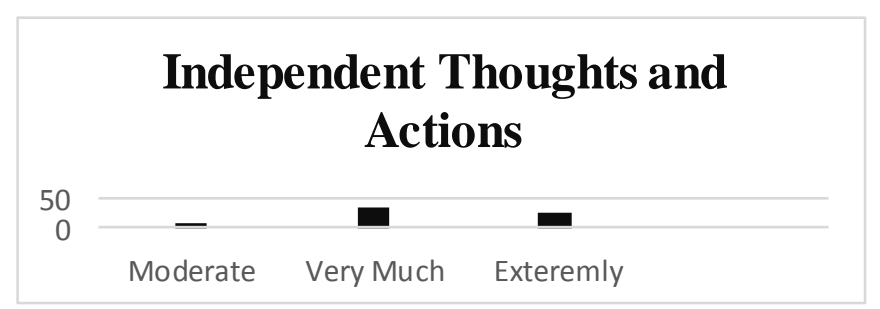

Figure 3. Dimension independent thoughts and actions

Regarding the job security, more than 56\% like having this extremely much as well as $33 \%$ like to have this very much (Figure 4).

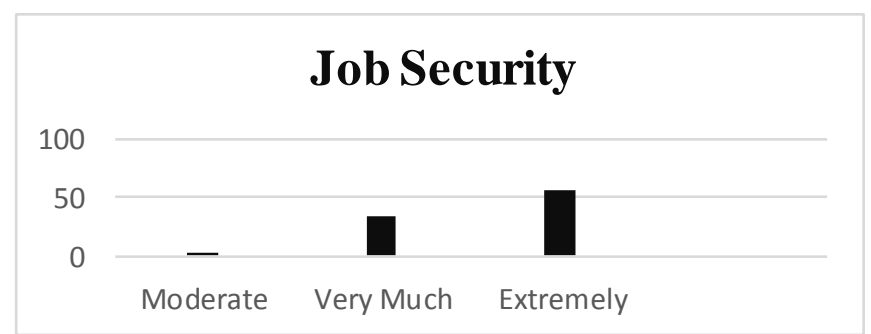

Figure 4. Dimension job security

For the friendly coworkers, the percentages were very close. $25 \%$ need to have it in a moderate amount and about $25 \%$ need to have it extremely much and $29 \%$ like to have this very much (Figure 5).

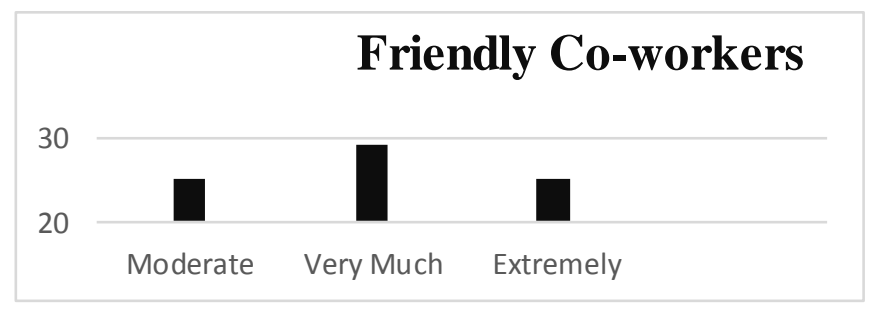

Figure 5. Dimension friendly co-workers

Regarding learning new things, 70\% like having this extremely much. However, only $4 \%$ like having this in a moderate amount (Figure 6). 


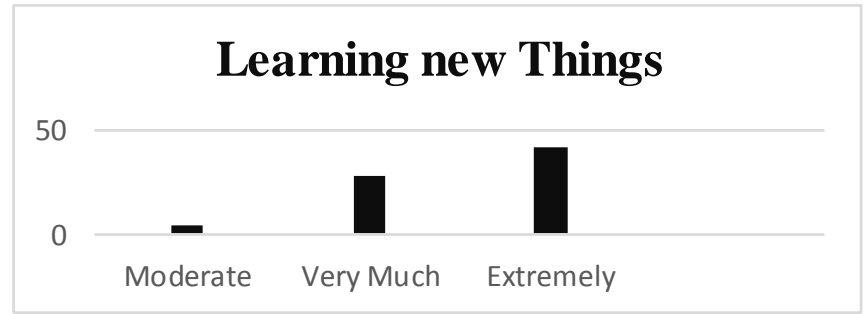

Figure 1. Dimension learning new things

Figure 7 shows the dimension salaries and benefits, the results showed that around $62 \%$ like having this characteristic extremely much. No one preferred having this in a moderate amount.

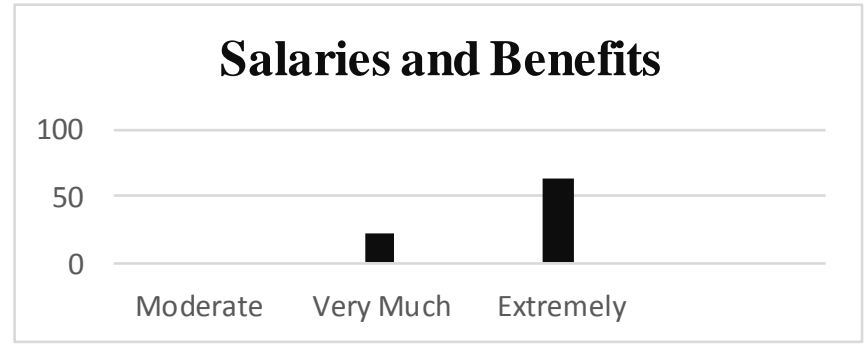

Figure 2. Dimension salaries and benefits

For the creativity, $36 \%$ liked having room for creativity at work extremely much. $22 \%$ preferred it very much (Figure 8).

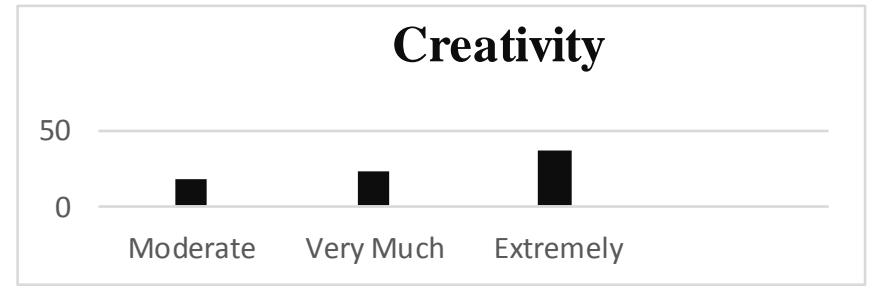

Figure 3. Dimension creativity

Regarding the quick promotion, 37\% like having this very much and $31 \%$ like having this extremely much. For personal growth, the majority (85\%) went for preferring it. For the last characteristic which is worthwhile accomplishments, participants were divided into extremely much $35 \%$ or very much $44 \%$. 
Table 1. Means and standard deviations of the dimensions

\begin{tabular}{|c|c|c|}
\hline & Mean & Std. Deviation \\
\hline Salaries and benefits & 6.05 & 1.33 \\
\hline Job security & 5.80 & 1.47 \\
\hline Learn new things & 5.50 & 1.59 \\
\hline Personal growth & 5.45 & 1.70 \\
\hline Worthwhile accomplishment & 5.45 & 1.33 \\
\hline Respect and fair treatment & 5.29 & 1.59 \\
\hline Quick promotion & 5.04 & 1.68 \\
\hline Independent thought and action & 4.83 & 1.71 \\
\hline Creativity & 4.63 & 2.26 \\
\hline Friendly co-workers & 3.97 & 2.24 \\
\hline Challenging work & 3.81 & 1.91 \\
\hline
\end{tabular}

The above table presents the means and standard deviations of all characteristics sorted from the highest mean to the lowest (Table 1).

Table 2. Statistical differences between means

\begin{tabular}{|c|c|c|c|c|c|}
\hline Source & DF & SS & MS & F & Probability \\
\hline Factors & 10 & 140691 & 14069 & 16.8 & 0.000000 \\
\hline Error & 1089 & 912056 & 838 & \multicolumn{2}{|l}{} \\
\cline { 1 - 4 } Total & 1099 & 1052746 & \multicolumn{1}{|l}{} \\
\cline { 1 - 4 }
\end{tabular}

The results of analysis of variance showed that there are statistically high significant differences between the means of individual characteristics $(\mathrm{P}<0.001)$ (Table 2$)$.

4.2 Z-Test for Two Mutually Exclusive Proportions from One Group

Table 3. Good pay vs. creative job

\begin{tabular}{|c|c|c|c|c|c|c|c|}
\hline & Strong & Slight & Total & Percentage & $\mathbf{Z}$ & Probability & \\
\hline A: Good pay & 43 & 14 & 57 & $60.6 \%$ & 2.11 & 0.0284 & P $<\mathbf{0 . 0 5}$ \\
\hline B: Creative job & 18 & 19 & 37 & $39.4 \%$ & & & \\
\hline & Total & 94 & & & & \\
\hline
\end{tabular}

The second part of the questionnaire highlighted several important trends among Egyptian 


\section{Macrothink}

World Journal of Business and Management ISSN 2377-4622 2016, Vol. 2, No. 2

employees with regard to their perception of good quality of work life. The results showed that $60.6 \%$ of those not responding neutral are preferring jobs that offer good pay than creative ones and this difference is statistically significance (Table 3 ).

Table 4. Important decisions vs. pleasant people

\begin{tabular}{|c|c|c|c|c|c|c|c|}
\hline & Strong & Slight & Total & Percentage & $\mathbf{Z}$ & Probability & \\
\hline A: Important decisions & 21 & 11 & 32 & $36.4 \%$ & -2.29 & 0.0222 & $P<0.05$ \\
\hline B: Pleasant people & 35 & 21 & 56 & $63.6 \%$ & & & \\
\hline & & Total & 88 & & & & \\
\hline
\end{tabular}

Regarding second question, $36.4 \%$ of those not responding neutral prefer jobs that require making important decisions and $63.6 \%$ prefer jobs that have opportunity to work with pleasant people. The difference is statistically significance $\mathrm{P}<0.05$ (Table 4).

Table 5. Performance vs. seniority

\begin{tabular}{|c|c|c|c|c|c|c|c|}
\hline & Strong & Slight & Tota & Percentag & $Z$ & Probability & \\
\hline A:Responsibility for best workers & 32 & 25 & 57 & $71.3 \%$ & 4.60 & 0.0000042 & P $<0.001$ \\
\hline B:Responsibility for senior people & 11 & 12 & 23 & $28.8 \%$ & & & \\
\hline & & Total & 80 & & & & \\
\hline
\end{tabular}

$71.3 \%$ prefer jobs in which responsibility is given to best workers and only $28.8 \%$ prefer jobs which responsibility is given to senior people and this difference is statistically highly significant $\mathrm{P}<0.001$ (Table 5).

Table 6. Financial trouble vs. no voice

\begin{tabular}{|c|c|c|c|c|c|c|c|}
\hline & Strong & Slight & Total & Percentage & $\mathbf{Z}$ & Probability & \\
\hline A: Financial trouble & 7 & 11 & 18 & $39.1 \%$ & -1.51 & 0.131 & $P>0.05$ \\
\hline B: No voice for anything & 9 & 19 & 28 & $60.9 \%$ & & & \\
\hline & & Total & 46 & & & & \\
\hline
\end{tabular}

However, when the respondents made a choice between jobs that face financial trouble and jobs where they are not allowed to say anything regarding their work schedule or procedures, 


\section{$\Lambda$ Macrothink}

World Journal of Business and Management

ISSN 2377-4622

2016, Vol. 2, No. 2

$39.1 \%$ of those not responding neutral are preferring alternative $\mathrm{A}$ and $60.9 \%$ prefer alternative $\mathrm{B}$ and this difference is statistically insignificant as $\mathrm{P}>0.05$ (Table 6).

Table 7. Routine vs. unfriendly atmosphere

\begin{tabular}{|c|c|c|c|c|c|c|c|}
\hline & Strong & Slight & Total & Percentage & $\mathbf{z}$ & Probability & \\
\hline A: Routine & 6 & 29 & 35 & $66.0 \%$ & 2.47 & 0.01380000 & $P<0.05$ \\
\hline B: Unfriendly coworker & 4 & 14 & 18 & $34.0 \%$ & & & \\
\hline & & Total & 53 & & & & \\
\hline
\end{tabular}

By comparing routine jobs or jobs where co-workers are not friendly, about $66 \%$ of those not responding neutral are preferring alternative A and 34\% prefer job B and this difference is statistically significant $\mathrm{P}<0.05$ (Table 7).

Table 8. Critical supervisor vs. no usage of skills

\begin{tabular}{|c|c|c|c|c|c|c|c|}
\hline & Strong & Slight & Total & Percentage & $\mathbf{Z}$ & Probability & \\
\hline A: Criticizing supervisor & 11 & 36 & 47 & $74.6 \%$ & 4.49 & 0.0000072 & $\mathrm{P}<0.001$ \\
\hline B: Prevent using skills & 2 & 14 & 16 & $25.4 \%$ & & & \\
\hline & & Total & 63 & & & & \\
\hline
\end{tabular}

$74.6 \%$ of the respondents prefer jobs that has criticizing supervisors than jobs that prevent them from using their skills and abilities. The difference is highly significant $\mathrm{P}<0.001$ (Table $8)$.

Table 9. Respect vs. learning

\begin{tabular}{|c|c|c|c|c|c|c|c|}
\hline & Strong & Slight & Total & Percentage & $\mathbf{Z}$ & Probability & \\
\hline A: Respect & 15 & 10 & 25 & $32.1 \%$ & -4.87 & 0.0000001 & $P<0.001$ \\
\hline B: Learning opportunity & 22 & 31 & 53 & $67.9 \%$ & & & \\
\hline & & Total & 78 & & & & \\
\hline
\end{tabular}

As shown in Table 9, the respondents statistically prefer alternative $\mathrm{B}$ than $\mathrm{A}(\mathrm{P}<0.001)$ as $67.9 \%$ prefer jobs that provide learning opportunities than jobs where supervisors respect them. 


\section{Ml Macrothink}

Table 10. Laying-off vs. no challenging work

\begin{tabular}{|c|c|c|c|c|c|c|c|}
\hline & Strong & Slight & Total & Percentage & $\mathbf{Z}$ & Probability & \\
\hline A: Laid off & 7 & 12 & 19 & $26.0 \%$ & -4.22 & 0.0000246 & $\mathbf{P}<\mathbf{0 . 0 0 1}$ \\
\hline B: No challenging work & 16 & 38 & 54 & $74.0 \%$ & & & \\
\hline & & Total & 73 & & & & \\
\hline
\end{tabular}

The proportion of responders preferring B is statistically significantly higher than preferring A

Participants prefer jobs where there is no challenging work $74 \%$ than job in which they can be laid off (26\%) (Table 10).

Table 11. Better skills vs. better benefits

\begin{tabular}{|l|c|c|c|c|c|c|c|}
\hline & Strong & Slight & Total & Percentage & $\mathbf{Z}$ & Probability & \\
\hline A: Develop skills & 19 & 15 & 34 & $35.4 \%$ & -2.99 & 0.0028000 & $\mathbf{P}<\mathbf{0 . 0 1}$ \\
\hline B: Good benefits & 35 & 27 & 62 & $64.6 \%$ & & & \\
\hline & & Total & 96 & & & & \\
\hline
\end{tabular}

The proportion of responders preferring B is statistically significantly higher than preferring A

Participants also prefer jobs that provide them with good benefits $64.6 \%$ than jobs that provide opportunities to develop skills $35.4 \%$ (Table 11).

Table 12. Little independency vs. poor conditions

\begin{tabular}{|c|c|c|c|c|c|c|c|}
\hline & Strong & Slight & Total & Percentage & $\mathbf{Z}$ & Probability & \\
\hline A: Little independency & 11 & 43 & 54 & $83.1 \%$ & 7.11 & 0.0000000 & $\mathbf{P}<\mathbf{0 . 0 0 1}$ \\
\hline B: Poor conditions & 4 & 7 & 11 & $16.9 \%$ & & & \\
\hline & & Total & 65 & & & & \\
\hline
\end{tabular}

The proportion of responders preferring A is statistically significantly higher than preferring B

The participants prefer jobs with little independency than jobs with poor working conditions $(\mathrm{P}<0.001)$ (Table 12).

Table 13. Teamwork vs. using abilities

\begin{tabular}{|c|c|c|c|c|c|c|c|}
\hline & Strong & Slight & Total & Percentage & $\mathbf{Z}$ & Probability & \\
\hline A: Teamwork & 19 & 26 & 45 & $51.7 \%$ & 0.32 & 0.7460000 & $P>0.05$ \\
\hline B:Use abilities & 17 & 25 & 42 & $48.3 \%$ & & & \\
\hline & & Total & 87 & & & & \\
\hline
\end{tabular}


However, there is an insignificant difference $(\mathrm{P}>0.05)$ between jobs that offer satisfying teamwork and jobs that allow employees to use abilities (Table 13).

Table 14. Unchallenging job vs. isolation

\begin{tabular}{|c|c|c|c|c|c|c|c|}
\hline & Strong & Slight & Total & Percentage & $\mathbf{Z}$ & Probability & \\
\hline A: Unchallenging & 14 & 42 & 56 & $75.7 \%$ & 5.15 & 0.0000002 & $P<0.001$ \\
\hline B: Isolated from coworkers & 3 & 15 & 18 & $24.3 \%$ & & & \\
\hline & & Total & 74 & & & & \\
\hline
\end{tabular}

The proportion of responders preferring A is statistically significantly higher than preferring B

Finally, participants prefer jobs that offer no challenging work than jobs where they can be isolated from co-workers (Table 14).

\section{Discussion}

The research question of this study was concerned with analyzing the perceptions of Egyptian employees regarding the quality of work life. The results from the present study showed that there are some dimensions of quality of work life that are more important than others. Although researchers proposed eight dimensions of quality of work life (Jayakumar \& Kalaiselvi, 2012; Kanten, 2014; Kaushik \& Tonk, 2008; Sundaray et al., 2013; Tatawar \& Nambudiri, 2014), however, they did not rank them. Participants reported salaries and benefits, job security and learning new things as the top three dimensions of good quality of work life. Such results are consistent with previous research as scholars often reported compensation as a very important requirement for satisfied employees (Kanten, 2014; Sundaray et al., 2013). The results showed that the salaries and benefits that employees get are the most important dimension of quality of work life in Egypt as the majority prefer jobs that offer good pay than others that offer creativity. Pranee also found that if employees were involved in an organization that did not provide adequate compensation, they would not put effort in achieving higher production levels (2010). When employees get fair compensation, it will reflect on their performance and productivity. However, other researchers believed that compensation is not sufficient for getting employees satisfied and increasing their performance. Other dimensions are required in order to increase satisfaction (Huang et al., 2007).

The results also showed that the second most important dimension is job security which is a non-monetary reward that employees receive (Noble, 2008). Job security is important as researchers believe that when employees feel secure, they will be more satisfied (Kanten, 2014; Noble, 2008) and face low levels of stress (Wang et al., 2014). When employees made a choice between jobs where they can be laid-off or jobs with no challenging work, the majority preferred jobs where there are no challenges which means that they do not prefer jobs where there is no job security. In addition, when they made a choice between jobs that are going for financial trouble and might disappear within one year or jobs where they are not 
allowed to have any say about work schedule and procedures, the majority preferred the job where they are not allowed to discuss their work schedule and procedures. This also confirms that job security is much more important for employees in Egypt. This could be attributed to the unstable economy. Organizations are down-sizing and laying-off high number of employees. Job security ensures employees that they will be able to cover their family responsibilities and any other financial obligations.

Personal growth and learning new things dimensions came in third place. The majority of participants prefer jobs that offer constant opportunities for learning new things over jobs with a supervisor who respects them. They prefer jobs which supervisors can criticize them over jobs than prevent them from using their abilities and skills. This confirms that the personal growth and learning new things are important than respect and that was supported by the researchers as they believed that all employees should have equal chances to grow, improve their abilities and skills and develop their personalities (Sundaray et al., 2013). The reason behind such preferences in Egypt could be attributed to employees seeking promotions or higher salaries. Nevertheless, this study provides evidence managers can use to improve the organizational effectiveness (Vidal-Salazar et al., 2012) as employees will be satisfied and performance levels will increase (Kanten, 2014) when they have room to grow.

The results of this study provide insights different from some of the previous researches. Al-Zboon et al. (2015) examined quality of work life among special education teachers in Jordan. Their analysis revealed that participants appreciated respect the most and rated participation in decision making as the least important dimension of quality of work life. In Oman, higher education teachers cared for level of stress, supervisory support and usage of skills as the most important when they were asked to highlight the most important aspects of quality of work life (Sathya Narayanan et al., 2012). The aforementioned scholars, in addition to Arun Vijay et al. (2014) agreed that age, gender and working experience interacted with the responses of participants. Such insights confirm that the dimensions of quality of work life, and their ranking, are not universal. They differ based on cultures, business fields, demographic variables and/or others.

\section{Conclusion}

The purpose of the study was to find out what are the most important dimensions of quality of work life in Egypt. It is important to note that quality of work life is a multidimensional concept. It means removing the undesirable behaviors and adding or modifying the working conditions in order to gain the desirable behaviors and a healthy environment. The results showed that salaries and benefits, job security and personal growth and learning new things are the most important dimensions of quality of work life for Egyptian employees.

The study had several limitations to be considered. First, the sample size was small (due to time and budget limitations) and the sample type was convenience which limit the ability to generalize the results. Second, all participants worked in private organizations, no exploration of public institutions was made. Third, the study did not analyze the effects of demographics on the ratings of the quality of work life dimensions. Finally, this study focused on one model which is Walton's model and did not use any other models such as the four factors model. 
For future research, it is suggested that exploration should be done on a larger scale to be able to generalize the results. Studies should focus on finding the differences between male and female employees' perception of quality of work life, if any. Exploration of cultural differences between Egypt as a developing country and other countries that are more developed is important.

For the practical implications within organizations, managers should find whether their employees' needs are satisfied or not. Managers should also identify the dimensions of quality of work life inside their organizations in terms of the most important dimensions in order to retain their employees and improve their productivity.

\section{References}

Al-Zboon, E. K., Al-Dababneh, K. A. H., \& Ahmad, J. (2015). Quality of work life: Perceptions of Jordanian special education teachers. Education, 13(3), 380-388.

Arun Vijay, S., Sekar, P. C., \& HemaVidhya, C. S. (2014). Quality of work life among the center workers in India: A cross sectional study. Global Management Review, 9(1), 1-11.

Chan, K. W., \& Wyatt, T. A. (2007). Quality of work life: A study of employees in Shanghai, $\begin{array}{lllll}\text { China. Asia Pacific Business } & \text { Review, }\end{array}$ http://dx.doi.org/10.1080/13602380701250681

Chitakornkijsil, P. (2010). Broad perspective and framework of quality of work life. International Journal of Organizational Innovation, 3(2), 214-242.

Christensen, L. J., Mackey, A., \& Whetten, D. (2014). Taking responsibility for corporate social responsibility: The role of leaders in creating, implementing, sustaining or avoiding socially responsible firm behaviors. The Academy of Management Perspectives, 28(2), 164-178. http://dx.doi.org/10.5465/amp.2012.0047

Cornell, P. T. (1984). Conditions influencing job performance and quality of work life in data entry task. $\mathrm{PhD}$ Thesis, The Pennsylvania State University.

Dehghan Nayeri, N., Salehi, T., \& Ali Asadi Noghabi, A. (2011). Quality of work life and productivity among Iranian nurses. Contemporary Nurse, 39(1), 106-118. http://dx.doi.org/10.5172/conu.2011.39.1.106

Hsu, M. Y., \& Kernohan, G. (2006). Dimensions of hospital nurses' quality of working life. Journal of Advanced Nursing, 120-131. http://dx.doi.org/10.1111/j.1365-2648.2006.03788.x

Huang, T. C., Lawler, J., \& Lei, C. Y. (2007). The effects of quality of work life on commitment and turnover intention. Social Behavior and Personality, 35(6), 735-750. http://dx.doi.org/10.2224/sbp.2007.35.6.735

Igbaria, M., Parasuraman, S., \& Badawy, M. K. (1994). Work experiences, job involvement, and quality of work life among information systems personnel. MIS Quarterly, 18(2), 175-201. http://dx.doi.org/10.2307/249764 
Islam, M. B. (2012). Factors affecting quality of work life: An analysis on employees of private limited companies in Bangladesh. Global Journal of Management and Business Research, 12(18), 22-31.

Jayakumar, A., \& Kalaiselvi, K. (2012). Quality of work life-An Overview. International Journal of Marketing-Financial Services \& Management Research, 1(10), 140-151.

Kanten, P. (2014). Effect of quality of work life (QWL) on proactive and prosocial organizational behaviors: A research on health sector employees. Suleyman Demirel University Journal of Faculty of Economics \& Administrative Sciences, 19(1), 251-274.

Kaushik, N., \& Tonk, M. S. (2008). Personality and quality of work life. Journal of Organizational Behavior, 7(3), 34-46.

McLain, D. L. (1995). Responses to health and safety risk in the work environment. Academy of Management Journal, 38(6), 1726-1743. http://dx.doi.org/10.2307/256852

Nagypal, N. C. (2014). Corporate social responsibility of Hungarian SMEs with good environmental practices. Journal of East European Management Studies, 19(3), 327-347.

Noble, C. H. (2008). The influence of job security on field sales manager satisfaction: Exploring frontline tensions. Journal of Personal Selling \& Sales Management, 28(3), 247-261. http://dx.doi.org/10.2753/PSS0885-3134280303

O’Reilly III, C.A., Caldwell, D.F. \& Barnett, W.P. (1989). Work group demography, social integration, and turnover. Administrative Science Quarterly, 34, 21-37.

Pranee, C. (2010). Quality of work life for sustainable development. International Journal of Organizational Innovation, 2(3), 124-137.

Rama Devi, V., \& Nagini, A. (2013). Work-life balance and burnout as predictors of job satisfaction in private banking sector. Skyline Business Journal, 9(1), 50-53.

Rathi, N. (2009). Relationship of quality of work life with employees' psychological well-being. International Journal of Business Insights \& Transformation, 3(1), 52-60.

Riches, V., \& Green, V. A. (2003). Social integration in the workplace for people with disabilities: An Australian perspective. Journal of Vocational Rehabilitation, 19(3), 127-142.

Saklani, D. R. (2010). Non-managerial perspective of quality of work life. Journal of Management Research, 10(2), 87-102.

Sathya Narayanan, S., Umaselvi, M., \& Ibrahim Hussein, M. (2012). Quality of work life and its impact on behavioural outcomes of teaching faculty: An empirical study in Oman higher education context. Skyline Business Journal, 8(1), 23-28.

Sundaray, B. K., Sahoo, C. K., \& Tripathy, S. K. (2013). Impact of human resource interventions on quality of work life: An exploration. International Employment Relations Review, 19(1), 68-86.

Tatawar, A. K., \& Nambudiri, R. (2014). Can fairness explain satisfaction? Mediation of 


\section{Macrothink}

World Journal of Business and Management

ISSN 2377-4622

2016, Vol. 2, No. 2

quality of work life (QWL) in the influence of organizational justice on job satisfaction. South Asian Journal of Management, 21(2), 101-122.

Vidal-Salazar, M. D., Huttado-Torres, N. E., \& Matias-Reche, F. (2012). Training as a generator of employee capabilities. The International Journal of Human Resource Management, 23(13), 2680-2697. http://dx.doi.org/10.1080/09585192.2011.610971

Wang, H., Ma, B., Liu, X., \& Liu, S. (2014). Job security and work outcomes in China: Perceived organizational support as mediator. Social Behavior and Personality: An International Journal, 42(7), 1069-1076.

Zare, H., Haghgooyan, Z., \& Karimi Asl, Z. (2014). Identification the components of quality of work life and measuring them in faculty of members of Tehran University. Iranian Journal of Management Studies, 7(1), 41-66.

\section{Copyright Disclaimer}

Copyright for this article is retained by the author(s), with first publication rights granted to the journal.

This is an open-access article distributed under the terms and conditions of the Creative Commons Attribution license (http://creativecommons.org/licenses/by/3.0/). 